\title{
ANALISIS PERLAKUAN AKUNTANSI ASET TETAP DALAM PENYUSUNAN NERACA PADA PEMERINTAHAN KABUPATEN MADIUN
}

\author{
Meigisanda Trias Saraswati ${ }^{1}$ \\ Pendidikan Akuntansi FKIP \\ Universitas PGRI Madiun \\ meigisandatriass@gmail.com
}

\author{
Satrijo Budiwibowo 2 \\ Pendidikan Akuntansi FKIP \\ Universitas PGRI Madiun \\ Satrijobudiwibowo@yahoo.com
}

\section{Nur Wahyuning Sulistyowati ${ }^{3}$ \\ Pendidikan Akuntansi FKIP \\ Universitas PGRI Madiun \\ nurwahyu@unipma.ac.id}

\begin{abstract}
ABSTRAK
Penelitian ini bertujuan untuk mengetahui perlakuan akuntansi aset tetap yang tercantum dalam neraca pemerintah Kabupaten Madiun pada tahun 2015 dan 2016 serta untuk mengetahui kesesuaian perlakuan akuntansi aset tetap dalam penyusunan neraca pemerintah Kabupaten Madiun pada tahun 2015 dan 2016 dengan Peraturan Pemerintah No. 71 Tahun 2010. Penelitian dilakukan di BPKAD Kabupaten Madiun dengan metode kualitatif. Hasil penelitian ini adalah perlakuan akuntansi aset tetap yang tercantum dalam neraca pemerintah Kabupaten Madiun pada tahun 2015 dan 2016 sudah sesuai dengan PP Nomor 71 tentang SAP PSAP No.07.
\end{abstract}

Kata Kunci: : Perlakuan Akuntansi Aset Tetap; Penyusunan Neraca Pemerintah

\section{ABSTRACT}

This study aims to determine the accounting treatment of fixed assets listed in the balance of government of Madiun Regency in 2015 and 2016 and to determine the suitability of accounting treatment of fixed assets in the preparation of the balance of government of Madiun Regency in 2015 and 2016 with Government Regulation no. 71 Year 2010. The research was conducted at BPKAD of Madiun Regency with qualitative method. The results of this study are the accounting treatment of fixed assets listed in the balance of government of Madiun Regency in 2015 and 2016 is in accordance with Government Regulation No. 71 on SAP PSAP No.07.

Keywords: Accounting Treatment of Fixed Assets; Government Balance Sheet Formulation

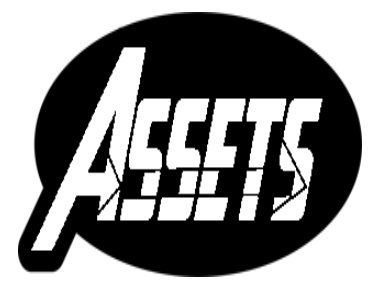

ASSETS

Jurnal Akuntansi dan Pendidikan

Vol. 6 No. 2

Hlmn. 152-167

Madiun, Oktober 2017 p-ISSN: 2302-6251 e-ISSN: 2477-4995

Artikel masuk: 16 Oktober 2017 Tanggal diterima: 25 Oktober 2017 


\section{PENDAHULUAN}

Pemerintah daerah maupun pemerintah pusat diwajibkan membuat laporan keuangan. Ambarawati \& Payamta (2015) berpendapat bahwa pemerintah daerah/kota merupakan salah satu organisasi sektor publik yang melaksanakan akuntansi sektor publik. Sebagai salah satu bagian dari sektor publik maka pemerintah daerah bertanggung jawab dalam pelaporan dari laporan keuangannya. Sulistyowati (2015) berpendapat bahwa laporan keuangan pada dasarnya adalah hasil dari proses akuntansi yang dapat digunakan sebagai alat untuk berkomunikasi dengan pihak yang berkepentingan dengan kondisi keuangan dan hasil operasi perusahaan. Neraca adalah laporan keuangan yang menggambarkan posisi keuangan suatu entitas pelaporan mengenai aset, kewajiban, dan ekuitas pada tanggal tertentu. Menurut Baridwan (2008:19) neraca adalah laporan yang menunjukkan keadaan keuangan suatu unit usaha pada tanggal tertentu. Sedangkan menurut Mursyidi (2009:71) neraca merupakan laporan yang disusun secara sistematis mengenai posisi aset, kewajiban, dan ekuitas dana untuk suatu entitas pada saat tertentu.

Aset merupakan akun yang dominan di dalam laporan neraca. Mulyadi (2008: 591) mengungkapkan bahwa aset tetap adalah kekayaan perusahaan yang memiliki wujud, mempunyai manfaat ekonomis lebih dari satu tahun, dan diperoleh perusahaan untuk melaksanakan kegiatan perusahaan, bukan untuk dijual kembali. Karena kekayaan ini mempunyai wujud, seringkali aktiva tetap disebut dengan aktiva tetap berwujud. Menurut Mardiasmo (2012:159) aktiva tetap adalah aktiva berwujud perusahaan yang dipergunakan dalam operasi perusahaan dan tidak dimaksudkan untuk dijual. Sedangkan Halim \& Kusufi (2012:117) berpendapat bahwa aset tetap adalah aset berwujud yang mempunyai masa manfaat lebih dari dua belas bulan untuk digunakan dalam kegiatan pemerintah atau dimanfaatkan oleh masyarakat umum.

Dalam rangka meningkatkan akuntabilitas pemerintah dalam menyajikan laporan keuangan, pemerintah mengeluarkan Peraturan Pemerintah Nomor 71 Tahun 2010 Tentang Standar Akuntansi Pemerintah. Perlakuan akuntansi aset tetap telah diatur dalam Pernyataan Standar Akuntansi Pemerintah Nomor 07 (PSAP 07) tentang akuntansi aset tetap yang merupakan lampiran dari Peraturan Pemerintah Nomor 07 Tahun 2010. Perlakuan akuntansi aset tetap meliputi pengakuan, pengukuran, pengeluaran setelah perolehan, penyusutan, penghentian dan pelepasan, dan pengungkapan aset tetap yang dimiliki pemerintah.

Penelitian terdahulu yang dilakukan Mardiana (2016), dengan hasil penelitian menunjukkan bahwa pengakuan, pengukuran dan penilaian aset tetap kendaraan bermotor roda empat Pemerintah Daerah Kabupaten Musi Banyuasin telah sesuai dengan Standar Akuntansi Pemerintah. Pengungkapan aset tetap saat penghapusan terdapat perbedaan pencatatan saat penghapusan aset tetap yaitu pada tahun 2013, 2014 dengan 2015. Pada penelitian Mayasani (2016), hasil penelitian menunjukkan bahwa kegiatan pencatatan dan pelaporan aset tetap yang dilakukan oleh Badan Pengelolaan Keuangan dan Aset Daerah Kota Kendari periode pembukuan tahun 2010-2012 belum sesuai dengan PP No.24 Tahun 2005 tentang Standar Akuntansi Pemerintah. Sedangkan Tipan, Saerang, \& Lambey, (2016), hasil penelitian menunjukkan bahwa pengakuan, pengukuran/penilaian, pengeluaran setelah perolehan, penghentian dan pelepasan, dan pengungkapan aset tetap pada Dinas Pekerjaan Umum (PU) Provinsi Sulawesi Utara telah sesuai dengan SAP No.07. Sedangkan untuk penyusutan aset belum pernah dilakukan penyusutan atas aset tetap dikarenakan belum adanya prosedur petunjuk teknis penyusutan aset tetap. 
Badan Pengelolaan Keuangan dan Aset Daerah (BPKAD) Kabupaten Madiun merupakan salah satu badan daerah di Kabupaten Madiun. BPKAD merupakan badan daerah yang memegang peranan dan fungsi strategis di bidang pengelolaan keuangan dan aset daerah Kabupaten Madiun.

Hasil wawancara peneliti pada staf bidang aset pada saat observasi awal terkait dengan standar akuntansi bahwa dengan adanya Peraturan Menteri Dalam Negeri Nomor 64 Tahun 2013 Tentang Penerapan Standar Akuntansi Pemerintahan Berbasis Akrual, kepala daerah dihimbau untuk menetapkan atau membuat peraturan kepala daerah tentang kebijakan akuntansi pemerintah daerah berbasis akrual. Sebelumnya standar akuntansi pemerintah yang berlaku yaitu Peraturan Pemerintah Nomor 24 tahun 2005 yang merupakan standar akuntansi yang digunakan untuk masa perubahan kas menuju akuntansi pemerintahan berbasis akrual. Oleh karena itu, pihak-pihak yang ahli bidang akuntansi di pemerintah Kabupaten Madiun membuat Peraturan Bupati Madiun Nomor 18 Tahun 2014 Tentang Kebijakan Akuntansi Pemerintah Kabupaten Madiun. Kebijakan akuntansi tersebut sudah menggunakan akuntansi berbasis akrual yang disesuaikan dengan keadaan atau kondisi di pemerintahan Kabupaten Madiun dalam perlakuan akuntansinya.

Setyaningsih \& Adilistiono (2015), menemukan bahwa perlakuan akuntansi pengakuan, pengukuran, penyajian, dan pengungkapan aset tetap pada Dinas Pengelolaan Keuangan dan Aset Daerah telah sesuai dengan penjelasan dalam Peraturan Pemerintah Nomor 71 Tahun 2010 tentang Standar Akuntansi Pemerintah, di mana penelitian ini dilakukan di Dinas Pengelolaan Keuangan dan Aset Daerah Kota Semarang. Sedangkan Putri, Sari, \& Sulistyowati, (2016), menemukan bahwa pengakuan, pengukuran, pengungkapan, penyusutan, penghentian dan penghapusan sesuai dengan Peraturan Pemerintah Nomor 71 Tahun 2010 tentang Standar Akuntansi Pemerintah Pernyataan Nomor 07 Akuntansi Aset Tetap, tetapi untuk penghentian dan penghapusan aset tetap di dalam neraca belum sepenuhnya sesuai dengan SAP serta untuk penilaian aset tetap tidak sesuai dengan SAP, penelitian ini dilakukan pada Badan Penanggulangan Bencana Daerah Kabupaten Tegal.

Berdasarkan uraian di atas, maka peneliti ingin menganalisis peralakuan akuntansi dan asal jumlah masing-masing aset tetap yang tercantum dalam neraca pemerintah Kabupaten Madiun. Perlakuan akuntansi yang dianalisis mulai dari pengakuan, pengukuran, pengeluaran setelah perolehan, penyusutan, penghentian dan pelepasan, serta pengungkapan hingga pelaporannya dalam neraca, serta kesesuaian implementasi dari Peraturan Bupati Madiun Nomor 18 Tahun 2014 Tentang Kebijakan Akuntansi Pemerintah Kabupaten Madiun sudah sesuai dengan Standar Akuntansi Pemerintah yang berlaku yaitu Peraturan Pemerintah Nomor 71 Tahun 2010.

\section{METODE PENELITIAN}

Penelitian ini merupakan penelitian kualitatif. Sugiyono (2014:15) mengemukakan bahwa metode penelitian kualitatif adalah metode penelitian yang berlandaskan pada filsafat postpositivisme, digunakan untuk meneliti pada kondisi obyek yang alamiah (sebagai lawannya adalah eksperimen) di mana peneliti adalah sebagai instrumen kunci, pengambilan sampel sumber data dilakukan secara purposive dan snowball, teknik pengumpulan dengan triangulasi (gabungan), analisis data bersifat induktif/kualitatif, dan hasil penelitian kualitatif lebih menekankan makna dari pada generalisasi. Jenis data penelitian ini merupakan data kualitatif bermakna. Sugiyono (2015:27) data kualitatif bermakna adalah data dibalik fakta yang tampak. Sedangkan menurut Darmadi (2013:286) penelitian kualitatif digunakan jika masalah 
belum jelas, untuk mengetahui makna yang tersembunyi, untuk memahami interaksi sosial, untuk mengembangkan teori, untuk memastikan kebenaran data, dan meneliti sejarah perkembangan.

Pada penelitian ini pada intinya peneliti menganalisis perlakuan akuntansi aset tetap mulai pengakuan, pengukuran, pengeluaran setelah perolehan, penyusutan, penghentian dan pelepasan, serta pengungkapan hingga pelaporannya dalam neraca, apakah implementasi dari Peraturan Bupati Madiun Nomor 18 Tahun 2014 Tentang Kebijakan Akuntansi Pemerintah Kabupaten Madiun sudah sesuai dengan Standar Akuntansi Pemerintah yang berlaku yaitu Peraturan Pemerintah Nomor 71 Tahun 2010.

Teknik pengumpulan data dalam penelitian ini melalui observasi, wawancara, dan dokumentasi. Peneliti melakukan observasi ke objek penelitian dengan cara bertanya kepada karyawan di objek penelitian. Narasumber wawancara dalam penelitian ini yaitu kepala sub bidang akuntansi sebagai informan ahli dan staf/karyawan sub bidang akuntansi serta kepala, staf/karyawan di sub bidang aset sebagai informan pendukung. Dokumentasi yang dilakukan oleh peneliti dalam penelitian ini dokumen yang terkait dengan perlakuan akuntansi aset tetap dalam penyusunan neraca pada Pemerintahan Kabupaten Madiun

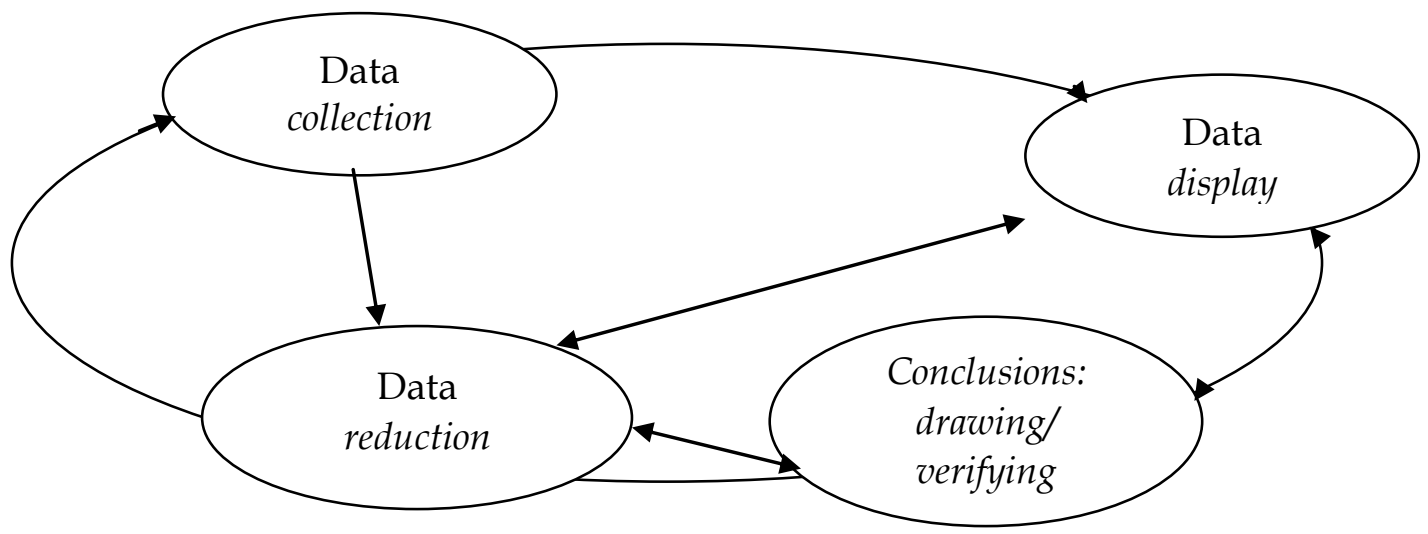

Gambar 1. Komponen dalam analisis data (Interactive Model)

Sumber: Sugiyono (2014:388)

Analisis data yang dilakukan dalam penelitian ini dengan tahap awal reduksi data kemudian setelah dilakukan reduksi data selanjutnya penyajian data, dan menyimpulkan data (verification). Selain analisis data tersebut dalam penelitian ini analisis data digunakan yaitu dengan metode analisis deskriptif komparatif atau perbandingan. Perbandingan yang dilakukan membandingkan penerapan perlakuan akuntansi aset tetap pada pemerintahan Kabupaten Madiun dengan Standar Akuntansi Pemerintah yang berlaku.

Teknik keabsahan data dalam penelitian ini menggunakan triangulasi. Triangulasi yang digunakan meliputi triangulasi sumber, triangulasi waktu, dan triangulasi teknik. Sehingga dapat memperoleh data hingga titik jenuh.

\section{HASIL PENELITIAN DAN PEMBAHASAN Perlakuan Akuntansi Aset Tetap}

Perlakuan akuntansi aset tetap pada penelitian ini didasarkan pada PSAP Nomor 07 tentang Aset Tetap, sehingga dari Peraturan Pemerintah berupa Standar Akuntansi Pemerintah yang berlaku menjadi dasar untuk dibandingkan dengan Peraturan Bupati Madiun Nomor 18 Tahun 2014 Tentang Kebijakan Akuntansi Pemerintah Kabupaten Madiun yang digunakan di pemerintahan Kabupaten Madiun guna mengetahui 
kesesuaian perlakuan akuntansi aset tetap pemerintah dalam penyusunan neraca pemerintahan Kabupaten Madiun dengan Standar Akuntansi Pemerintah yang berlaku.

\section{a. Pengakuan Aset Tetap}

Didapatkan hasil bahwa pengakuan aset tetap yang dimiliki Kabupaten Madiun harus memenuhi kriteria aset tersebut harus berwujud dan memiliki masa manfaat 12 bulan. Biaya-biaya dalam perolehan aset harus dapat diukur secara handal serta aset tetap yang dimiliki tidak dimaksudkan untuk dijual dalam aktivitas operasi melainkan aset tersebut diperoleh atau dibangun dengan maksud untuk digunakan serta dalam memperoleh aset atau pengeluaran atas aset tetap harus memenuhi batasan minimal kapitalisasi aset tetap yang telah ditetapkan.

Tabel 1. Perbandingan Pengakuan Aset Tetap

\begin{tabular}{|c|c|c|}
\hline PP Nomor 17 tahun 2010 (SAP) & $\begin{array}{c}\text { Perbub Nomor } 18 \text { tahun } 2014 \\
\text { (Kabupaten Madiun) }\end{array}$ & Keterangan \\
\hline $\begin{array}{l}\text { Untuk dapat diakui sebagai aset } \\
\text { tetap, suatu aset harus } \\
\text { berwujud dan memenuhi } \\
\text { kriteria: } \\
\text { - Mempunyai masa manfaat } \\
\text { lebih dari } 12 \text { (dua belas) } \\
\text { bulan } \\
\text { - Biaya perolehan aset dapat } \\
\text { diukur secara andal } \\
\text { - Tidak dimaksudkan untuk } \\
\text { dijual dalam operasi normal } \\
\text { entitas an dibangun } \\
\text { Diperoleh atau } \\
\text { dengan maksud untuk } \\
\text { digunakan }\end{array}$ & $\begin{array}{l}\text { Untuk dapat diakui sebagai aset } \\
\text { tetap harus dipenuhi kriteria } \\
\text { sebagai berikut: } \\
\text { - Berwujud } \\
\text { - Mempunyai masa manfaat } \\
\text { lebih dari } 12 \text { (dua belas) bulan } \\
\text { - Biaya perolehan aset dapat } \\
\text { diukur secara andal } \\
\text { - Tidak dimaksudkan untuk } \\
\text { dijual dalam operasi normal } \\
\text { entitas } \\
\text { Diperoleh atau dibangun } \\
\text { dengan maksud untuk } \\
\text { digunakan } \\
\text { Nilai rupiah pembelian barang } \\
\text { material atau pengeluaran } \\
\text { untuk pembelian barang } \\
\text { tersebut memenuhi batasan } \\
\text { minimal kapitalisasi aset tetap } \\
\text { yang telah ditetapkan }\end{array}$ & Sesuai \\
\hline
\end{tabular}

Staf bidang aset menjelaskan bahwa pengakuan aset tetap dilakukan apabila ada pengadaan barang dari belanja modal dan memenuhi syarat kebijakan akuntansi. Sedangkan menurut staf bidang akuntansi, pengakuan aset dilakukan setelah diterbitkannya SP2D (Surat Perintah Pencairan Dana).

Pengakuan aset tetap akan lebih andal apabila telah terjadi perpindahan hak kepemilikan atau penguasaan secara hukum. Apabila perolehan aset tetap tidak didukung dengan bukti secara hukum, sebagai contohnya masih dalam proses administrasi, proses jual beli, dan belum adanya sertifikat kepemilikan maka aset tetap yang bersangkutan belum dapat diakui sebagai aset tetap. Aset tetap diakui apabila sudah terjadi perpindahan kepemilikan secara resmi.

\section{b. Pengukuran Aset Tetap}

Pengukuran aset tetap Pemerintah Kabupaten Madiun penilaian aset tetap didasarkan pada harga perolehan aset tetap. Pada saat perolehan apabila tidak memungkinkan didasarkan pada harga perolehan maka penilaian aset tetap didasarkan pada harga wajar sesuai dengan ketentuan maupun kesepakatan pada saat 
perolehan aset tetap. Sesuai dengan penjelasan dari Kepala Sub Bidang Akuntansi yang menyatakan bahwa:

"Untuk pengukuran nilai aset tetap yaitu kaitannya aset tetap atau gabungan maka pada saat pengeluaran biaya dalam memperoleh aset tetap yang bersangkutan. Contohnya pada saat membeli tanah harganya sekian tetapi pada saat rapat terdapat biaya tambahan yang menambah dari saat memperoleh terkait aset tersebut maka biaya tersebut diakui sebagai perolehan aset tetap yang bersangkutan."

Di pemerintah Kabupaten Madiun, pengukuran aset disesuaikan dengan cara pengadaan aset yang bersangkutan. Pengadaan aset dapat dilakukan dengan pengadaan langsung, pelelangan sederhana atau umum. Pengadaan barang dengan cara tersebut harga perolehan aset tetap ditentukan oleh PPKom (Pejabat Pembuat Komitmen) dengan melakukan survey harga pasar, internet, penawaran, atau menentuan penawaran dari penyedia. Harga aset yang bersangkutan ditambah dengan biaya yang dikeluarkan untuk memperoleh aset, misal honor panitia pengadaan. Pengukuran aset tetap sebesar harga perolehannya. Di dalam belanja modal jumlah nilai barang ditambah biaya-biaya lain yang bersangkutan dengan proses perolehan aset tetap.

Biaya perolehan aset tetap merupakan biaya yang dikeluarkan pada saat memperoleh aset tetap yang bersangkutan sehingga menambah nilai perolehan aset tetap. Perolehan aset tetap berupa tanah dinilai dengan biaya perolehan. Biaya perolehan tanah diantaranya harga pembelian tanah serta biaya yang dikeluarkan dalam memperoleh tanah hingga siap untuk digunakan. Biaya yang dikeluarkan dalam perolehan tanah antara lain biaya pengurusan sertifikat, peningkatan bukti kepemilikan tanah apabila status tanah girik menjadi SHM, biaya jual beli, biaya pengukuran tanah, dan biaya lainnya. Biaya perolehan peralatan dan mesin diantarnya harga pembelian peralatan dan mesin serta biaya yang dikeluarkan dalam memperolehnya. Biaya tersebut diantaranya biaya pengangkutan, biaya instalasi, biaya pemasangan, dan biaya lainnya.

Apabila aset tetap diperoleh secara gabungan, maka tetap diklasifikasikan. Perhitungannya dialokasian berdasarkan nilai wajar sesuai klasifikasi aset tetap. Sehingga dalam perolehan secara gabungan, perhitungan harga perolehan dipisahpisahkan sesuai klasifikasi, lalu digabungkan atau ditambahkan. Sedangkan untuk aset tetap diperoleh secara pertukaran, aset harga perolehan disesuaikan dengan nilai aset tetap yang dilepas dengan nilai yang diserahkan. Selama ini pertukaran aset tetap dilakukan dengan pemerintah pusat. Apabila suatu aset akan digunakan oleh pemerintah pusat untuk kepentingan tertentu, maka diganti nilainya sesuai aset yang digunakan pada saat itu. Tetapi penggantian tersebut tidak berupa uang tetapi dengan aset tetap yang sama klasifikasinya. Apabila diperoleh secara donasi (sumbangan) maka penentuan harga perolehannya ditentukan berdasarkan harga wajar pada saat perolehan. Perolehan secara donasi selama ini yaitu hibah dari pemerintah pusat.

Tabel 2. Perbandingan Pengukuran Aset Tetap

\begin{tabular}{llll}
\hline PP Nomor 17 tahun 2010 (SAP) & $\begin{array}{c}\text { Perbub Nomor 18 tahun 2014 } \\
\text { ( Kabupaten Madiun) }\end{array}$ & Keterangan \\
\hline $\begin{array}{l}\text { Aset tetap dinilai dengan harga } \\
\text { perolehan. Apabila penilaian }\end{array}$ & $\begin{array}{l}\text { Aset tetap dinilai dengan biaya } \\
\text { perolehan. Apabila penilaian }\end{array}$ & \\
aset tetap dengan menggunakan & aset tetap dengan menggunakan & \\
biaya perolehan tidak & biaya perolehan tidak & \\
memungkinkan maka nilai aset & memungkinkan maka nilai aset & \\
tetap didasarkan pada nilai & tetap didasarkan pada nilai & \\
wajar pada saat perolehan. & wajar pada saat perolehan. & \\
\hline
\end{tabular}




\begin{tabular}{|c|c|c|}
\hline PP Nomor 17 tahun 2010 (SAP) & $\begin{array}{l}\text { Perbub Nomor } 18 \text { tahun } 2014 \\
\text { ( Kabupaten Madiun) }\end{array}$ & Keterangan \\
\hline $\begin{array}{l}\text { Biaya perolehan dari masing- } \\
\text { masing aset tetap yang diperoleh } \\
\text { secara gabungan ditentukan } \\
\text { dengan mengalokasikan harga } \\
\text { gabungan tersebut berdasarkan } \\
\text { perbandingan nilai wajar } \\
\text { masing-masing aset yang } \\
\text { bersangkutan. }\end{array}$ & $\begin{array}{l}\text { Biaya perolehan dari masing- } \\
\text { masing aset tetap yang diperoleh } \\
\text { secara gabungan ditentukan } \\
\text { dengan mengalokasikan harga } \\
\text { gabungan tersebut berdasarkan } \\
\text { perbandingan nilai wajar masng- } \\
\text { masing aset yang bersangkutan. }\end{array}$ & Sesuai \\
\hline $\begin{array}{l}\text { Suatu aset tetap dapat diperoleh } \\
\text { melalui pertukaran atau } \\
\text { pertukaran sebagai aset tetap } \\
\text { yang tidak serupa atau aset } \\
\text { lainnya. Biaya dari pos semacam } \\
\text { itu diukur berdasarkan nilai } \\
\text { wajar aset yang diperoleh yaitu } \\
\text { nilai ekuivalen atas nilai tercatat } \\
\text { aset yang dilepas setelah } \\
\text { disesuaikan dengan jumlah } \\
\text { setiap kas atau setara kas yang } \\
\text { ditransfer/ diserahkan. }\end{array}$ & $\begin{array}{l}\text { Suatu aset tetap dapat diperoleh } \\
\text { melalui pertukaran atau } \\
\text { pertukaran sebagai aset tetap } \\
\text { yang tidak serupa atau aset } \\
\text { lainnya. Biaya dari pos semacam } \\
\text { itu diukur berdasarkan nilai } \\
\text { wajar aset yang diperoleh, yaitu } \\
\text { nilai ekuivalen atas nilai tercatat } \\
\text { aset yang dilepas setelah } \\
\text { disesuaikan dengan jumlah } \\
\text { setiap kas atau setara kas yang } \\
\text { ditransfer/ diserahkan. }\end{array}$ & Sesuai \\
\hline $\begin{array}{l}\text { Aset tetap yang diperoleh dari } \\
\text { sumbangan (donasi) harus } \\
\text { dicatat sebesar nilai wajar pada } \\
\text { saat perolehan. }\end{array}$ & $\begin{array}{l}\text { Aset tetap yang diperoleh dari } \\
\text { sumbangan (donasi) harus } \\
\text { dicatat sebesar nilai wajar pada } \\
\text { saat perolehan. }\end{array}$ & Sesuai \\
\hline
\end{tabular}

\section{c. Pengeluaran Setelah Perolehan Aset Tetap}

Berdasarkan pertanyaan yang diajukan terkait dengan pengeluaran setelah perolehan apa saja yang dikeluarkan untuk aset tetap, kepala sub bidang akuntansi menjelaskan bahwa:

"Biaya-biaya rutin atau biaya pemeliharaan yang dilakukan untuk aset tetap tidak termasuk pengeluaran setelah perolehan aset tetap. Biaya tersebut tidak menambah masa aset tetap yang bersangkutan. Biaya yang dikeluarkan setelah perolehan yaitu biaya yang menambah nilai aset tetap."

Di Pemerintahan Kabupaten Madiun perawatan bangunan yang merupakan usaha untuk memperbaiki kerusakan yang terjadi agar bangunan dapat berfungsi dengan baik sebagaimana mestinya perawatan bangunan digolongkan sesuai dengan tingkat kerusakan pada bangunan. Pemeliharaan jalan dan jembatan merupakan upaya menjaga kondisi jalan dan jembatan agar selalu dapat berfungsi dengan baik, pemeliharaan jalan dan jembatan dikategorikan berdasarkan pemeliharaan rutin. Pemeliharaan jaringan atau bangunan air merupakan upaya menjaga dan mengamankan jaringan irigasi atau bangunan air agar selalu dapat berfungsi dengan baik guna memperlancar operasional, maka pemeliharaan jaringan irigasi atau bangunan air juga diklasifikasikan berdasarkan pemeliharaan. 
Tabel 3. Perbandingan Pengeluaran Setelah Perolehan Aset Tetap

\begin{tabular}{|c|c|c|}
\hline PP Nomor 17 tahun 2010 (SAP) & $\begin{array}{c}\text { Perbub Nomor } 18 \text { tahun } 2014 \\
\text { (Kabupaten Madiun) }\end{array}$ & Keterangan \\
\hline $\begin{array}{l}\text { Pengeluaran setelah perolehan } \\
\text { awal suatu aset tetap yang } \\
\text { memperpanjang masa manfaat } \\
\text { atau yang kemungkinan besar } \\
\text { memberi manfaat ekonomik di } \\
\text { masa yang akan datang dalam } \\
\text { bentuk kapasitas, mutu } \\
\text { produksi, atau peningkatan } \\
\text { standar kinerja, harus } \\
\text { ditambahkan pada nilai } \\
\text { tercatat aset } \\
\text { bersangkutan. }\end{array}$ & $\begin{array}{l}\text { Pengeluaran setelah perolehan } \\
\text { awal suatu aset tetap yang } \\
\text { memperpanjang masa manfaat } \\
\text { atau yang kemungkinan besar } \\
\text { memberi manfaat ekonomi di } \\
\text { masa yang akan datang dalam } \\
\text { bentuk peningkatan kapasitas/ } \\
\text { volume, peningkatan efisiensi, } \\
\text { peningkatan mutu produksi, } \\
\text { penambahan fungsi, atau } \\
\text { peningkatan standar kinerja } \\
\text { yang nilainya sebesar nilai } \\
\text { satuan minimum kapitalisasi } \\
\text { aset tetap atau lebih, harus } \\
\text { ditambahkan pada nilai tercatat } \\
\text { (dikapitalisasi) aset yang } \\
\text { bersangkutan. }\end{array}$ & Sesuai \\
\hline
\end{tabular}

\section{d. Penyusutan Aset Tetap}

Dibuktikan dengan penyusutan aset tetap di Pemerintahan Kabupaten Madiun aset tetap selain tanah dan konstruksi dalam pengerjaan disusutkan nilainya berdasarkan umur ekomomis atau masa manfaat dan tarif penyusutan aset tetap yang bersangkutan. Nilai penyusutan untuk masing-masing periode diakui sebagai pengurang nilai tercatat aset tetap dalam neraca berupa akumulasi penyusutan aset tetap sebagai pengurangan nilai aset tetap. Pemerintahan Kabupaten Madiun perhitungan penyusutan aset tetap dilakukan perbulan dan akan diakumulasi jumlah penyusutan masing-masing aset tetap selama satu periode atau satu tahun dan disajikan dalam laporan neraca.

Metode penyusutan aset tetap Pemerintahan Kabupaten Madiun yaitu menggunakan metode garis lurus (straight line method). Aset tetap disusutkan berdasarkan masa manfaat atau umur ekonomis dan tarif penyusutan yang berbedabeda sesuai dengan jenis aset tetap yang disusutkan yang telah ditetapkan dalam kebijakan akuntansi Kabupaten Madiun.

Tabel 4. Perbandingan Penyusutan Aset Tetap

\begin{tabular}{|c|c|c|}
\hline PP Nomor 17 tahun 2010 (SAP) & $\begin{array}{l}\text { Perbub Nomor } 18 \text { tahun } 2014 \\
\text { ( Kabupaten Madiun) }\end{array}$ & Keterangan \\
\hline $\begin{array}{l}\text { Aset tetap disajikan berdasarkan } \\
\text { biaya perolehan aset tetap } \\
\text { tersebut dikurangi akumulasi } \\
\text { penyusutan. Apabila terjadi } \\
\text { kondisi yang memungkinkan } \\
\text { penilaian kembali, maka aset } \\
\text { tetap akan disajikan dengan } \\
\text { penyesuaian pada masing- } \\
\text { masing akun aset tetap dan akun } \\
\text { diinvestasikan dalam aset tetap. }\end{array}$ & $\begin{array}{l}\text { Penyusutan merupakan alokasi } \\
\text { yang sistematis atas nilai suatu } \\
\text { aset tetap yang dapat } \\
\text { disusutkan (depreciable assets) } \\
\text { selama masa manfaat aset yang } \\
\text { bersangkutan. } \\
\text { penyusutan untuk masing- } \\
\text { masing periode diakui sebagai } \\
\text { pengurang nilai tercatat aset } \\
\text { tetap dalam neraca dan beban } \\
\text { penyusutan dalam laporan }\end{array}$ & Sesuai \\
\hline
\end{tabular}


PP Nomor 17 tahun 2010 (SAP) $\quad$ Perbub Nomor 18 tahun $2014 \quad$ Keterangan ( Kabupaten Madiun)

operasional.

Metode penyusutan yang dapat dipergunakan antara lain:

1. Metode garis lurus (straight line method)

Metode penyusutan yang

Sesuai dipergunakan adalah Metode

Garis Lurus (straight line method).

2. Metode saldo menurun ganda ( double declining balance method)

3. Metode unit produksi (unit of production method)

\section{e. Penghentian dan Pelepasan Aset Tetap}

Penghentian dan pelepasan aset tetap di Pemerintahan Kabupaten Madiun bahwa aset tetap yang dimiliki Pemerintahan Kabupaten Madiun dieliminasi atau dikeluarkan dari neraca ketika dilepaskan atau dihentikan penggunaannya. Aset tetap yang dilepaskan atau dihentikan secara permanen penggunaanya dalam aktivitas operasi pemerintah dikarenakan aset tetap tersebut sudah habis masa manfaatnya atau tidak memberikan manfaat ekonomi di masa yang akan datang.

Tabel 5. Perbandingan Penghentian dan Pelepasan Aset Tetap

\begin{tabular}{llll}
\hline PP Nomor 17 tahun 2010 (SAP) & $\begin{array}{c}\text { Perbub Nomor 18 tahun 2014 } \\
\text { ( Kabupaten Madiun) }\end{array}$ & Keterangan \\
\hline Suatu aset tetap dieliminasi dari & $\begin{array}{l}\text { Suatu aset tetap dieliminasi dari } \\
\text { Sesuai }\end{array}$ \\
neraca ketika dilepaskan atau & neraca ketika dilepaskan atau & \\
bila aset secara permanen & bila aset secara permanen & \\
dihentikan penggunaannya dan & dihentikan penggunaannya dan & \\
tidak ada manfaat ekonomik & tidak ada manfaat ekonomi masa & \\
masa yang akan datang. & yang akan datang. & \\
\hline
\end{tabular}

Tindak lanjut yang dilakukan apabila aset tetap dihentikan atau dilepaskan yaitu dilakukan penghapusan aset. Penghapusan aset dilakukan oleh tim lelang. Guna melepaskan aset tetap terdapat tim serta penilainya, aset tetap dalam artian dijual oleh tim tersebut. Apabia nilainya besar seperti akan menambah PAD dalam artian suatu aset tetap tidak layak lalu dilepas atau dihentikan maka nilainya harus ada. Penentuan nilai aset dengan memakai lembaga lelang sehingga aset setelah ada yang dibeli dilihat dasar surat pembelian lewat kantor lelang tersebut selanjutnya baru dilepaskan. Penghapusan dilakukan setelah ada SK (Surat Keputusan) penghapusan dari bupati.

\section{f. Pengungkapan Aset Tetap}

Pengungkapan aset tetap di Pemerintahan Kabupaten Madiun masing-masing aset tetap diungkapkan dalam laporan keuangan. Laporan keuangan harus mengungkapkan dasar penilaian yang digunakan untuk menentukan nilai tercatat dalam laporan keuangan. Rekonsiliasi jumlah tercatat pada awal dan akhir periode laporan keuangan berupa penambahan aset tetap, pelepasan aset tetap, akumulasi penyusutan dan perubahan nilai. Informasi penyusutan yang meliputi nilai penyusutan, metode penyusutan aset tetap yang digunakan, masa manfaat atau tarif penyusutan aset tetap yang digunakan, dan nilai tercatat bruto dan akumulasi penyusutan pada awal dan akhir periode akuntansi.

Pengungkapan aset tetap dalam neraca yaitu jumlah setiap klasifikasi aset atau nilai perolehan masing-masing aset tetap serta akumulasi penysutan aset tetap. Pengungkapan aset tetap pada laporan keuangan yaitu di neraca pengungkapanya 
terkait dengan jumlah masing-masing aset tetap juga akumulasi penyusutan aset tetap. Hal ini sesuai dengan keterangan staf bagian akuntansi terkait pengungkapan aset tetap, bahwa:

"Pengungkapan aset tetap di lampiran 1.7 pada Perda diharapkan menyajikan dalam laporan keuangan yang menunjukkan rekap saldo belanja modal aset berupa belanja, kapitalisasi aset, reklasifikasi aset, penghapusan dan sebagainya yang diungkapkan di CaLK dan laporan keuangan lainnya."

Kalau di CaLK mengungkapkan kebijakan, asumsi, prinsip-prinsip, metode penyusutan, masa manfaat dan yang terkait dengan aset tetap. Pada laporan arus kas hanya menyajikan arus kas terkait aset tetap saja. Sedangkan laporan realisasi anggaran menyajikan realisasi dari belanja aset-aset yang dimiliki.

Tabel 6. Perbandingan Pengungkapan Aset Tetap

\begin{tabular}{|c|c|c|}
\hline $\begin{array}{c}\text { PP Nomor } 17 \text { tahun } 2010 \\
\text { (SAP) }\end{array}$ & $\begin{array}{l}\text { Perbub Nomor } 18 \text { tahun } 2014 \\
\text { ( Kabupaten Madiun) }\end{array}$ & Keterangan \\
\hline $\begin{array}{l}\text { Laporan keuangan harus } \\
\text { mengungkapkan } \\
\text { masing-masing jenis aset tetap } \\
\text { sebagai berikut: }\end{array}$ & $\begin{array}{l}\text { Laporan keuangan harus } \\
\text { mengungkapkan } \\
\text { masing-masing jenis aset tetap } \\
\text { sebagai berikut: }\end{array}$ & Sesuai \\
\hline $\begin{array}{l}\text { 1. Dasar penilaian yang } \\
\text { digunakan } \\
\text { menentukan nilai tercatat } \\
\text { (carrying amount) }\end{array}$ & $\begin{array}{l}\text { 1. Dasar penilaian yang } \\
\text { digunakan } \\
\text { menentukan nilai tercatat } \\
\text { (carrying amount) }\end{array}$ & \\
\hline $\begin{array}{l}\text { 2. Rekonsiliasi jumlah tercatat } \\
\text { pada awal dan akhir } \\
\text { periode }\end{array}$ & $\begin{array}{l}\text { 2. Rekonsiliasi jumlah tercatat } \\
\text { pada awal dan akhir } \\
\text { periode }\end{array}$ & \\
\hline 3. Informasi penyusutan & 3. Informasi penyusutan & \\
\hline
\end{tabular}

\section{Neraca Pemerintahan Kabupaten Madiun}

Laporan neraca merupakan laporan yang menyajikan salah satunya yaitu aset tetap. Jumlah atau nilai tercatat aset tetap dalam neraca Pemerintah Kabupaten Madiun merupakan harga atau nilai perolehan sesuai klasifikasi aset tetap. Berikut perbandingan jumlah aset tetap Kabupaten Madiun tahun 2015 dan 2016.

Tabel 7. Perbandingan Neraca Pemerintahan Kabupaten Madiun (Aset Tetap) Tahun 2016 dan 2015

\begin{tabular}{lrr}
\hline \multicolumn{1}{c}{ Jenis Aset Tetap } & \multicolumn{1}{c}{$\mathbf{2 0 1 6}$} & \multicolumn{1}{c}{$\mathbf{2 0 1 5}$} \\
\hline Tanah & $276.448 .239 .430,00$ & $253.350 .709 .762,00$ \\
Peralatan dan Mesin & $383.299 .508 .540,61$ & $336.107 .564 .698,78$ \\
Gedung dan Bangunan & $775.792 .088 .901,33$ & $676.060 .413 .488,41$ \\
Jalan, Irigasi, dan Jaringan & $4.501 .437 .737 .618,96$ & $4.278 .723 .719 .703,96$ \\
Aset Tetap Lainnya & $11.904 .375 .285,94$ & $11.351 .580 .285,94$ \\
Konstruksi Dalam Pengerjaan & $49.753 .843 .003,00$ & $6.005 .798 .000,00$ \\
Akumulasi Penyusutan & $(2.695 .635 .393 .047,67)$ & $(2.297 .983 .334 .826,00)$ \\
\hline Jumlah Aset Tetap & $3.303 .000 .399 .732,17$ & $3.263 .616 .451 .113,09$ \\
\hline
\end{tabular}

\section{Sumber: BPKAD Kabupaten Madiun 2017}

Berdasarkan tabel 7 di atas mengenai jenis aset tetap di neraca Pemerintah Kabupaten Madiun untuk periode tahun 2015 dan 2016 dapat dilihat bahwa aset tetap yang dimiliki pemerintah Kabupaten Madiun yaitu tanah peralatan dan mesin, gedung 


\section{ASSEIS JURNAL AKUNTANSI DAN PENDIDIKAN

dan bangunan, jalan, irigasi, dan jaringan, aset tetap lainnya, konstruksi dalam pengerjaan.

\section{a. Tanah}

Tanah yang dimiliki Pemerintahan Kabupaten Madiun pada tahun 2015 sebesar Rp 253.350.709.762,00 dan pada tahun 2016 sebesar Rp 276.448.239.430,00. Sehingga dari tahun 2015 menuju 2016 mengalami kenaikan sebesar Rp 23.097.529,668,00. Perbedaan atau selisih dari jumlah tanah tersebut dibuktikan dengan adanya penambahan pada belanja modal tanah realisasi tahun 2016 sebesar Rp 22.981.911.000,00 dan reklasifikasi menjadi aset tanah dari KIB C menjadi KIB A sebesar Rp 549.216.668,00 yang merupakan pematangan lahan pematangan lahan area parkir pengembangan taman wisata Umbul oleh Dinas Pekerja Umum Bina Marga. Pengurangan yang terjadi karena adanya reklasifikasi aset dari tanah ke jalan dari KIB A ke KIB D sebesar Rp 433.598.000,00 di RSUD Dolopo (pemavingan lahan).

\section{b. Peralatan dan Mesin}

Peralatan dan mesin yang dimiliki Pemerintahan Kabupaten Madiun dari tahun 2015 sebesar Rp 336.107.564.698,78 dan pada tahun 2016 sebesar Rp 383.299.508.540,61. Sehingga dari tahun 2015 menuju 2016 mengalami kenaikan sebesar Rp 47.191.943.841,83. Perbedaan atau selisih dari jumlah peralatan dan mesin tersebut dibuktikan dengan adanya penambahan pada belanja modal peralatan dan mesin realisasi tahun 2016 sebesar Rp 46.404.956.498,93 serta dari pemerintah pusat sebesar Rp 2.803.217.900,00. Penambahan lainnya berasal dari reklasifikasi aset sebesar Rp 966.976.635,00 yang direklasifikasi dari aset yang lain menjadi peralatan dan mesin.

Pengurangan yang terjadi karena diserahkan kepada pihak ketiga yaitu alat kantor dan rumah tangga untuk sekolah swasta dan desa sebesar Rp 38.192.500,00 dari Kantor Lingkungan Hidup dan diserahkan ke bidan swasta berupa alat-alat kedokteran sebesar Rp 164.471.428,00 dari Badan KB dan BP dan adanya penyerahan aset berupa alat-alat angkutan kepada sekolah swasta dan desa sebesar Rp 15.180.000,00 dari Kantor Lingkungan Hidup sehingga dilakukan penghapusan aset terkait. Pengurangan lain berasal dari reklasifikasi aset sebesar Rp 2.765.363.264,10 yang direklasifikasi dari peralatan dan mesin menjadi aset tetap yang lain.

\section{c. Gedung dan Bangunan}

Gedung dan bangunan yang dimiliki Pemerintahan Kabupaten Madiun pada tahun 2015 gedung dan bangunan sebesar Rp 676.060.413.488,41 dan pada tahun 2016 Rp 775.792.088.901,33. Sehingga dari tahun 2015 menuju 2016 mengalami kenaikan sebesar Rp 99.731.675.412,92. Perbedaan atau selisih dari jumlah gedung dan bangunan tersebut dibuktikan dengan adanya penambahan pada belanja modal gedung dan bangunan realisasi tahun 2016 sebesar Rp 149.350.906.013,00 dan reklasifikasi aset dari konstruksi dalam pengerjaan pada DPU Binamarga sebesar Rp 430.111.000,00 dan reklasifikasi aset dari aset lainnya di Kecamatan Dolopo terkait rehabiltasi pagar kantor kecamatan sebesar Rp 19.700.000,00. Reklasifikasi aset dari barang dan jasa menjadi jalan dan jembatan pada Dinas Koperasi sebesar Rp 17.166.668,00, Dinas PU Binamarga sebesar Rp 396.584.000,00 dan Kelurahan Wungu sebesar Rp 6.930.000,00. Penambahan lain berasal dari reklasifikasi aset dari aset yang lain menjadi aset gedung dan bangunan sebesar Rp Rp 426.802.442,00.

Penurunan dikarenakan adanya reklasifikasi menjadi aset gedung dan bangunan menjadi aset tanah sebesar Rp 549.216.668,00 yang merupakan pematangan lahan area parkir pengembangan taman wisata Umbul oleh Dinas Pekerja Umum Binamarga. Reklasifikasi aset ke aset berupa jalan di DPU Binamarga sebesar Rp 130.249.319,00 dan di Dinas Koperasi sebesar Rp 374.949.000,00 serta reklasifikasi dari gedung dan bangunan ke aset yang lain sebesar Rp 47.009.740.408,08. Pengurangan adanya 
penyerahan aset berupa monumen dari Dinas Kebersihan Pertamanan ke masyarakat sebesar Rp 201.266.666,00. Pengurangan lain berasal dari adanya penghapusan aset gedung dan bangunan di Dinas Kesehatan sebesar Rp 879.943.000,00, RSUD Caruban sebesar Rp 1.838.970,00, BPKAD sebesar Rp 504.404.800,00, Kecamatan Kare sebesar Rp 203.040.879,00, Kecamatan Dolopo sebesar Rp 10.000.000,00, dan Dinas Pendapatan sebesar Rp 1.051.875.000,00.

\section{d. Jalan, Irigasi, dan Jaringan}

Jalan, irigasi, dan jaringan yang dimiliki Pemerintahan Kabupaten Madiun pada tahun 2015 sebesar Rp 4.278.723.719.703,96 dan pada tahun 2016 sebesar Rp 4.501.437.737.618,96. Sehingga dari tahun 2015 menuju tahun 2016 mengalami kenaikan sebesar Rp 222.714.017.915,00. Perbedaan atau selisih dari jumlah jalan, irigasi, dan jaringan tersebut dibuktikan dengan adanya penambahan pada belanja modal jalan, irigasi, dan jaringan realisasi tahun 2016 sebesar Rp 221.146.452.974,00. Penambahan dari adanya reklasifikasi aset dari tanah ke jalan dari sebesar Rp 433.598.000,00 di RSUD Dolopo (pemavingan lahan), reklasifikasi aset dari aset gedung dan bangunan Dinas PU Binamarga sebesar Rp 130.249.319,00 dan Dinas Koperasi sebesar Rp 374.949.000,00. Penambahan lain reklasifikasi aset tetap konstruksi dalam pekerjaan menjadi jalan, irigasi, dan jaringan pada Dinas PU Pengairan sebesar Rp 639.049.000,00 dan reklasifikasi dari aset tetap lainnya menjadi aset jalan, jaringan, dan irigasi berupa pemasangan lampu PJU (Penerangan Jalan Umum) sebesar Rp 124.483.000,00 pada Dinas Kebersihan dan Pertamanan. Reklasifikasi aset tetap peralatan dan mesin (penyempurnaan tendon air) sebesar Rp 29.337.000,00 di RSUD Dolopo. Reklasifikasi barang dan jasa pada Dinas PU Pengairan sebsar Rp 49.650.000,00, Dinas Peternakan dan Perikanan sebesar Rp 10.822.222,00 berupa bangunan air/ irigasi serta Dinas Kesehatan sebesar Rp 19.900.000,00 berupa instalasi. Penambahan lain yang berasal dari reklasifikasi aset tetap yang lain menjadi aset jalan, irigasi, dan jaringan sebesar Rp 1.667.638.900,00.

Pengurangan dikarekanakan adanya reklasifikasi aset di Dinas PU Binamarga menjadi barang dan jasa sebesar Rp 19.250.000,00 serta reklasifikasi aset jalan, irigasi, dan jaringan menjadi aset tetap yang lain sebesar Rp 1.172.699.500,00. Pengurangan dengan penyerahan kepada masyarakat dari Dinas Kebersihan Pertamanan sebesar Rp 394.312.000,00 serta dari Dinas Kehutanan dan Perkebunan aset berupa jalan, irigasi, dan jaringan diserahkan ke masyarakat di desa Bader Kec.Dolopo sebesar Rp 162.940.000,00 dan desa Balok Kec. Gemarang sebesar Rp 162.910.000,00.

\section{e. Aset Tetap Lainnya}

Aset tetap lainnnya yang dimiliki Pemerintahan Kabupaten Madiun pada tahun 2015 sebesar Rp 11.351.580.285,94 dan pada tahun 2016 sebesar Rp 11.904.375.285,94. Sehingga dari tahun 2015 menuju tahun 2016 aset tetap lainnya mengalami kenaikan sebesar Rp 552.795.000,00. Perbedaan atau selisih dari jumlah aset tetap lainnya tersebut dibuktikan dengan adanya penambahan pada belanja modal aset tetap lainnya realisasi tahun 2016 sebesar Rp 1.797.343.750,00 dan reklasifikasi dari alat pertanian sebesar Rp 2.000.000,00 pada Bagian Umum. Pertambahan aset lainnya juga berasal dari hibah dari pemerintah pusat sebesar Rp 6.000.000,00 pada Dinas Pendidikan berupa barang bercorak kebudayaan.

Pengurangan dari aset tetap lainnya berasal dari reklasifikasi dari barang dan jasa menjadi barang bercorak kebudayaan sebesar Rp 550.000,00 pada Bagian Kesejahteraan Rakyat dan sebesar Rp 54.320.000,00 pada Dinas Pendidikan. Pengurangan lainya berasal dari reklasifikasi aset dari barang dan jasa menjadi aset buku dan perpustakaan sebesar Rp 1.178.678.750,00 pada Dinas Pendidikan serta 
reklasifikasi software peta digital mobil perpustakaan keliling sebesar Rp 19.000.000,00 pada Kantor Perpustakaan.

\section{f. Konstruksi dalam Pengerjaan}

Konstruksi dalam pengerjaan yang dimiliki Pemerintahan Kabupaten Madiun pada tahun 2015 sebesar Rp 6.005.798.000,00 dan pada tahun 2016 sebesar Rp 49.753.843.003,00. Sehingga pada tahun 2015 menuju tahun 2016 konstruksi dalam pengerjaan juga mengalami peningkatan sebesar Rp 43.748.045.003,00. Perbedaan atau selisih dari penambahan dari konstruksi dalam pengerjaan yang dilakukan pada tahun 2016 reklasifikasi aset dari barang dan jasa menjadi konstruksi dalam pengerjaan sebesar Rp 143.529.000,00 pada Dinas PU Binamarga terkait pembangunan Padepokan Madiun Kampung Pesilat. Pertambahan konstruksi dalam pengerjaan lainnya dari Dinas PU Binamarga sebesar Rp 45.190.014.003,00 dan Badan Ketahanan Pangan sebesar Rp 14.500.000,00.

Pengurangan jumlah konstruksi dalam pengerjaan dikarenakan adanya konstruksi dalam pengerjaan yang telah selesai pada tahun 2016 sehingga mengurangi jumlah konstruksi dalam pngerjaan yaitu pada Dinas PU Binamarga berupa bangunan gedung sebesar Rp 430.111.000,00 dan jalan atau jembatan sebesar Rp 517.550.000,00. Konstruksi dalam pengerjaan pada Dinas PU Pengairan sebesar Rp 639.049.000,00 berupa bangunan air serta pada Kantor Lingkungan Hidup sebesar Rp 13.288.000,00.

\section{SIMPULAN}

Perlakuan akuntansi aset tetap pengakuan, pengukuran, pengeluaran setelah perolehan, penyusutan, penghentian dan pelepasan, serta pengungkapan aset tetap yang tercantum dalam neraca pemerintah Kabupaten Madiun pada tahun 2015 dan 2016 sudah sesuai dengan Peraturan Pemerintah Nomor 71 tentang Standar Akuntansi Pemerintah PSAP No.07. Perlakuan akuntansi aset tetap dalam penyusunan neraca pemerintah Kabupaten Madiun sudah sesuai dengan Peraturan Pemerintah Nomor 71 Tahun 2010 Tentang Standar Akuntansi Pemerintah, dibuktikan dengan adanya Laporan Hasil Pemeriksaan (LHP) atas Laporan Keuangan Pemerintah Daerah Kabupaten Madiun tahun 2016 dengan Opini Wajar Tanpa Pengecualain (WTP).

Hasil penelitian ini, diharapkan Pemerintah Kabupaten Madiun tetap mempertahankan perlakuan akuntansi aset tetap meliputi pengakuan aset tetap, pengukuran aset tetap, pengeluaran setelah perolehan aset tetap, penyusutan aset tetap, penghentian dan pelepasan aset tetap, dan pengungkapan aset tetap sesuai dengan Standar Akuntansi Pemerintah sehingga dapat mempertahankan Opini Wajar Tanpa Pengecualian (WTP) untuk tahun selanjutnya. Pemerintah Kabupaten Madiun diharapkan tetap mempertahankan pencatatannya di neraca sesuai dengan Peraturan Pemerintah Nomor 71 Tahun 2010 tentang Standar Akuntansi Pemerintah dengan aset tetap dicatat sebesar biaya perolehan masing-masing aset tetap. Untuk memperjelas perlakuan akuntansi aset tetap dalam penyusunan neraca bagi pembaca laporan keuangan, jumlah akumulasi penyusutan untuk masing-masing aset tetap disajikan sesuai dengan klasifikasinya.

Pada penelitian ini perlakuan akuntansi hanya meliputi akun-akun aset tetap yang tercantum dalam neraca. Penelitian selanjutnya dapat meneliti akun-akun aset lancar, kewajiban, dan ekuitas yang tercantum dalam laporan neraca serta analisis yang lebih mendalam terkait dengan perlakuan akuntansi aset tetap atau perlakuan akuntansi dari akun-akun aset lancar, kewajiban, dan ekuitas. 


\section{DAFTAR PUSTAKA}

Ambarawati, A. dan Payamta. (2015). Pengaruh Pendapatan Asli Daerah, Investasi Pemerintah dan Angkatan Kerja Terhadap Produk Domestik Regional, Bruto Kabupaten/Kota di Jawa. ASSETS: Jurnal Akuntansi dan Pendidikan, 4 (1), 3752.

Baridwan, Z. (2008). Intermediate Accounting. Yogyakarta: BPFE-Yogyakarta.

Darmadi, H. (2014). Dimensi-dimensi Metode Penelitian Pendidikan dan Sosial. Bandung: Alfabeta.

Halim, A \& Muhammad Syam, K. (2012). Akuntansi Sektor Publik: Akuntansi Keuangan Daerah. Jakarta: Salemba Empat.

Mardiana. (2016). Analisis Akuntansi Aset Tetap Kendaraan Bermotor Roda Empat Pemerintah Daerah Kabupaten Musi Banyuasin. Jurnal Akuntansi Politeknik Sekayu (ACSY), 5 (2), 24-36.

Mardiasmo.(2012). Akuntansi Keuangan Dasar 2. Yogyakarta: BPFE-Yogyakarta.

Mayasani, D. M., (2016). Evaluasi Pencatatan dan Pelaporan Aset Tetap Pemerintah

Daerah Pada Badan Pengelolaan Keuangan dan Aset Daerah (BPKAD) Kota

Kendari. Jurnal Akuntansi (JAk), 1 (1), 14-29.

Mulyadi. (2008). Sistem Akuntansi. Jakarta: Salemba Empat

Mursyidi. (2009). Akuntansi Pemerintahan di Indonesia. Bandung: PT Refika Aditama.

Sulistyowati, N. W. (2015). Analisis Laporan Keuangan Sebagai Alat Ukur Untuk Menilai Kinerja Keuangan PT Pelabuhan Indonesia di Surabaya. ASSETS: Jurnal Akuntansi dan Pendidikan, 4 (2), 99-107

Peraturan Pemerintah Republik Indonesia Nomor 71 Tahun 2010 Tentang Standar Akuntansi Pemerintah.

Putri, R. A. F. P., Sari, P., dan Sulistyowati, D. (2016). Analisis Perlakuan Akuntansi Aset Tetap Berdasarkan Pernyataan Standar Akuntansi Pemerintahan No 07 pada Badan Penanggulangan Bencana Daerah Kabupaten Tegal. Account, 3 (2), 508-513.

Setyaningsih, M., dan Adilistiono (2015). Perlakuan Akuntansi Aset Tetap Pada Dinas Pengelolaan Keuangan dan Aset Daerah Kota Semarang. Teknis, 10 (3), 128-136.

Sugiyono. (2014). Metode Penelitian Pendidikan (Pendekatan Kuantitatif, Kualitatif, dan R\&D). Bandung: Alfabeta.

Sugiyono. (2015). Cara Mudah Menyusun Skripsi, Tesis, dan Disertasi. Bandung: Alfabeta.

Tipan, A., Saerang, D. P. E., dan Lambey, R., (2016). Analisis Perlakuan Akuntansi Aset Tetap pada Dinas Pekerjaan Umum (PU) Provinsi Sulawesi Utara. Jurnal Riset Akuntansi Going Concern, 11 (1), 57-65. 
LAMPIRAN

Pedoman Wawancara Perlakuan Akuntansi

\begin{tabular}{|c|c|}
\hline Indikator & Pertanyaan \\
\hline Neraca & $\begin{array}{l}\text { 1. Bagaimana tahap-tahap dalam penyusunan neraca pemerintah? } \\
\text { 2. Menurut anda, pos apakah yang paling utama dalam } \\
\text { penyusunan neraca pemerintah? } \\
\text { 3. Bagaimana tahap-tahap penyajian aset tetap dalam neraca? } \\
\text { 4. Menurut anda, kendala apa saja yang dialami dalam tahap } \\
\text { penyajian aset tetap dalam neraca? }\end{array}$ \\
\hline $\begin{array}{l}\text { Perlakuan } \\
\text { Akuntansi } \\
\text { Aset Tetap }\end{array}$ & $\begin{array}{l}\text { 1. Apakah yang anda ketahui mengenai perlakuan akuntansi aset } \\
\text { tetap? } \\
\text { 2. Menurut Anda, apakah tujuan perlakuan akuntansi aset tetap? } \\
\text { 3. Bagaimana penerapan perlakuan akuntansi dalam penyusunan } \\
\text { laporan neraca pemerintahan? } \\
\text { 4. Adakah permasalahan yang terjadi dalam penerapan perlakuan } \\
\text { akuntansi aset tetap dalam penyusunan neraca? } \\
\text { 5. Menurut Anda, penerapan perlakuan akuntansi aset tetap } \\
\text { (pengakuan, pengukuran, pengeluaran setelah perolehan, } \\
\text { penyusutan, penghentian dan pelepadan, dan pengungkapan) } \\
\text { manakah yang tersulit dalam penerapannya? }\end{array}$ \\
\hline Pengakuan & $\begin{array}{l}\text { 1. Bagaimana suatu aset/aktiva dapat diakui sebagai aset tetap? } \\
\text { 2. Bagaimana pengakuan yang dilakukan untuk aset tetap berupa } \\
\text { tanah, peralatan dan mesin, gedung dan bangunan, jalan, irigasi, } \\
\text { dan jaringan, konstruksi dalam pengerjaan, dan aset tetap } \\
\text { lainnya? } \\
\text { 3. Menurut Anda, apakah tujuan dengan diterapkannya perlakuan } \\
\text { akuntansi aset tetap berupa pengakuan aset tetap? }\end{array}$ \\
\hline Peng & $\begin{array}{l}\text { 1. Bagaimana pengukuran yang dilakukan untuk aset tetap berupa } \\
\text { tanah, peralatan dan mesin, gedung dan bangunan, jalan, irigasi, } \\
\text { dan jaringan, konstruksi dalam pengerjaan, dan aset tetap } \\
\text { lainnya? } \\
\text { 2. Bagaimana pengukuran aset tetap pada saat diperoleh secara } \\
\text { gabungan? } \\
\text { 3. Bagaimana pengukuran aset tetap pada saat diperoleh secara } \\
\text { pertukaran aset? } \\
\text { 4. Bagaimana pengukuran aset tetap pada saat diperoleh dari } \\
\text { sumbangan (donasi)? } \\
\text { 5. Menurut Anda, apakah tujuan dengan diterapkannya perlakuan } \\
\text { akuntansi aset tetap berupa pengukuran aset tetap? }\end{array}$ \\
\hline $\begin{array}{l}\text { Pengeluaran } \\
\text { Setelah } \\
\text { Perolehan }\end{array}$ & $\begin{array}{l}\text { 1. Pengeluaran setelah perolehan apa saja yang dikeluarkan untuk } \\
\text { aset tetap berupa tanah, peralatan dan mesin, gedung dan } \\
\text { bangunan, jalan, irigasi, dan jaringan, konstruksi dalam } \\
\text { pengerjaan, dan aset tetap lainnya? } \\
\text { 2. Menurut Anda, apakah tujuan dengan diterapkannya perlakuan } \\
\text { akuntansi aset tetap pengeluaran setelah perolehan aset tetap? }\end{array}$ \\
\hline Penyusutan & $\begin{array}{l}\text { 1. Apakah metode penyusutan yang digunakan untuk penyusutan } \\
\text { aset tetap? } \\
\text { 2. Bagaimana metode penyusutan aset tetap dan dasar menentukan } \\
\text { masa manfaat aset tetap berupa tanah, peralatan dan mesin, }\end{array}$ \\
\hline
\end{tabular}


SARASWATI, M. T., BUDIWIBOWO, S. \& SULISTYOWATI, N. W. ANALISIS PERLAKUAN AKUNTANSI ....

\begin{tabular}{|c|c|}
\hline Indikator & Pertanyaan \\
\hline & $\begin{array}{l}\text { gedung dan bangunan, jalan, irigasi, dan jaringan, konstruksi } \\
\text { dalam pengerjaan, dan aset tetap lainnya? } \\
\text { 3. Menurut Anda, apakah tujuan dengan diterapkannya perlakuan } \\
\text { akuntansi aset tetap penyusutan aset tetap? }\end{array}$ \\
\hline $\begin{array}{l}\text { Penghentian } \\
\text { dan Pelepasan }\end{array}$ & $\begin{array}{l}\text { 1. Bagaimana suatu aset tetap dieliminasi dari neraca ketika } \\
\text { dihentikan atau dilepaskan? } \\
\text { 2. Bagaimana perlakuan atau tindak lanjut setelah aset tetap } \\
\text { dihentikan atau dilepaskan? } \\
\text { 3. Menurut Anda, apakah tujuan dengan diterapkannya perlakuan } \\
\text { akuntansi aset tetap penghentian dan pelepasan aset tetap? }\end{array}$ \\
\hline Pengungkapan & $\begin{array}{l}\text { 1. Bagaimana pengungkapan aset tetap dalam laporan neraca? } \\
\text { 2. Adakah laporan keuangan lainnya yang mengungkapkan terkait } \\
\text { dengan aset tetap? } \\
\text { 3. Apa saja yang diungkapkan dalam pengungkapan aset tetap } \\
\text { dalam laporan keuangan? } \\
\text { 4. Bagaimana perlakuan akuntansi aset tetap pengungkapan aset } \\
\text { tetap berupa tanah, peralatan dan mesin, gedung dan bangunan, } \\
\text { jalan, irigasi, dan jaringan, konstruksi dalam pengerjaan, dan aset } \\
\text { tetap lainnya? } \\
\text { 5. Menurut Anda, apakah tujuan dengan diterapkannya perlakuan } \\
\text { akuntansi aset tetap pengungkapan aset tetap? }\end{array}$ \\
\hline \multicolumn{2}{|r|}{ Pedoman Wawancara Penyusunan Neraca } \\
\hline Indikator & Pertanyaan \\
\hline Tanah & $\begin{array}{l}\text { Di neraca untuk tanah tahun } 2015 \text { sebesar } R p \text { 253.350.709.762,00 dan } \\
\text { pada tahun } 2016 \text { sebesar Rp 276.448.239.430,00 terlihat adanya kenaikan } \\
\text { itu berasal dari mana? }\end{array}$ \\
\hline $\begin{array}{l}\text { Peralatan } \\
\text { dan Mesin }\end{array}$ & $\begin{array}{l}\text { Di neraca untuk peralatan dan mesin tahun } 2015 \text { sebesar Rp } \\
\text { 336.107.564.698,78 dan pada tahun } 2016 \text { sebesar } \mathrm{Rp} 383.299 .508 .540,61 . \\
\text { terlihat adanya kenaikan itu berasal dari mana? }\end{array}$ \\
\hline $\begin{array}{l}\text { Gedung } \\
\text { dan } \\
\text { Bangunan }\end{array}$ & $\begin{array}{l}\text { Di neraca untuk gedung dan bangunan tahun } 2015 \text { sebesar Rp } \\
676.060 .413 .488,41 \text { dan pada tahun } 2016 \mathrm{Rp} 775.792 .088 .901,33 \text { terlihat } \\
\text { adanya kenaikan itu berasal dari mana? }\end{array}$ \\
\hline $\begin{array}{l}\text { Jalan, } \\
\text { irigasi, dan } \\
\text { Jaringan }\end{array}$ & $\begin{array}{l}\text { Di neraca untuk jalan, irigasi, dan jaringan tahun } 2015 \text { sebesar Rp } \\
\text { 4.278.723.719.703,96 dan pada tahun } 2016 \text { sebesar Rp } \\
\text { 4.501.437.737.618,96 terlihat adanya kenaikan itu berasal dari mana? }\end{array}$ \\
\hline $\begin{array}{l}\text { Aset Tetap } \\
\text { Lainnya }\end{array}$ & $\begin{array}{l}\text { Di neraca untuk aset tetap lainnya tahun } 2015 \text { sebesar Rp } \\
\text { 11.351.580.285,94 dan pada tahun } 2016 \text { sebesar Rp 11.904.375.285,94 } \\
\text { terlihat adanya kenaikan itu berasal dari mana? }\end{array}$ \\
\hline $\begin{array}{l}\text { Konstruksi } \\
\text { dalam } \\
\text { Pengerjaan }\end{array}$ & $\begin{array}{l}\text { Di neraca untuk konstruksi dalam pengerjaan pada tahun } 2015 \text { sebesar } \\
\text { Rp 6.005.798.000,00 dan pada tahun } 2016 \text { sebesar Rp } 49.753 .843 .003,00 \\
\text { terlihat ada kenaikan itu berasal dari mana? }\end{array}$ \\
\hline
\end{tabular}

